\title{
ARTICLES
}

\section{ISLAM IN CHINA: THE HĀN KITĀB TRADITION IN THE WRITINGS OF WANG DAIYU, MA ZHU AND LIU ZHI, WITH A NOTE ON THEIR RELEVANCE FOR CONTEMPORARY ISLAM}

\author{
Alexander Wain*
}

\begin{abstract}
This paper examines the unique Chinese brand of Islam known as the Hān Kitāb. Beginning with a brief historical overview of the Sinicised Muslim community which created this tradition, the paper proceeds to examine the work of three key Hān Kitāb figures: Wang Daiyu, Ma Zhu and Liu Zhi. All active between the mid-seventeenth and early eighteenth centuries, the paper argues that their utilisation of the Islamic concept of dīn al-fitra (or humanity's innate inclination towards a belief in God), coupled with a willingness to engage positively with Neo-Confucian thought, resulted in a uniquely multicultural form of Islam; the Hān Kitāb, we will conclude, represents an early example of Islamic 'ecumenical thought'. By actively seeking to appreciate and acknowledge the commonalities between Islam and Chinese tradition, the Hān Kitāb overcame exclusivism and stressed moderation. In the context of the challenges posed by contemporary Salafi-inspired Islamic extremism, this paper will argue that the Hān Kitāb has never been more relevant than it is today.
\end{abstract}

\section{Introduction}

This paper examines the Hui (Sinicised Muslim) ${ }^{1}$ tradition known as the Hān Kitäb (from the Chinese han qitabu, lit. a Chinese Islamic book). Although a conceptually sophisticated and rich tradition, very little is known about the Hān Kitāb - or, for that matter, the Muslim community which created it outside a handful of (almost entirely western) scholars. Given this level of unfamiliarity, our paper will begin with a brief historical survey, outlining the history of the Hui up until the mid-seventeenth century, when the first Hān Kit $\bar{a} b$ texts began to emerge. This background will serve as historical context, helping to illuminate the tradition as a whole. Our paper will then examine the 
Hān Kitāa's three key figures: Wang Daiyu, Ma Zhu and Liu Zhi. All active between the mid-seventeenth and early eighteenth centuries, each writer will be examined in turn. Ultimately, we will argue that their work, emerging amidst a unique set of cultural and linguistic circumstances, came to rest on the Islamic concept of din al-fitra - or of humanity's innate inclination towards a belief in God. Via both this concept and a close comparison of Neo-Confucianism and Islam, these Hān Kitāb writers were able to justify giving Confucius prophetic status. This step, we will argue, resulted in a uniquely multicultural form of Islam. As Syed Farid Alatas has stressed, in the contemporary world Islam has struggled to engage meaningfully with other religions. ${ }^{2}$ In line with S. Murata, we will conclude that the Hān Kitāb represents an early example of Islamic 'ecumenical thought'; drawing upon concepts integral to the Islamic tradition, the Hān Kitāb actively appreciated and acknowledged the commonalities between different religions, thereby overcoming exclusivism and stressing moderation. ${ }^{3}$ In the context of the challenges posed by contemporary Salafiinspired Islamic extremism, our paper will argue that the Hān Kitāb has never been more relevant than it is today.

\section{The History of Islam in China up until the Seventeenth Century}

How and when Islam first arrived in China is uncertain. An early eighteenthcentury Hān Kitāb text, however, the Huihui Yuanlai (The Origins of the Hui), attributed to Liu Sanjie (the father of Liu Zhi), ${ }^{4}$ claims China's Muslim community was first established in 651, by a man named Sahabo Sahadi Wogesi - that is, by șahāba Sa'd ibn Abī Waqqās, the Prophet Muḥammad's maternal uncle. ${ }^{5}$ Although this legend remains very prevalent amongst contemporary Hui, it has not found widespread acceptance elsewhere. Rather, mainstream scholarship prefers to date China's first Muslim settlements to $c a .748$, when the Japanese monk, Kanshin, noted Persian and Arab mercantile settlements at both Hainan and Guangzhou (in Guangdong province). ${ }^{6}$ Certainly, by the end of the Tang dynasty (618-907), China's Muslim population was both wellestablished and substantial. ${ }^{7}$ Composed primarily of sojourning Persian and Arab merchants, by the end of the Song dynasty (960-1279) it had spread right across China, with important concentrations in the southern coastal provinces of Guangdong and Fujian. ${ }^{8}$ The advent of the Mongol Yuan dynasty (12711368), however, saw China's Muslim population suddenly increase in both size and importance.

During their Asian campaigns, the Mongols enslaved a large number of Central Asian and Persian Muslims, co-opting them into their army and later resettling them in China. ${ }^{9}$ Moreover, because the Mongols were a traditionally 
nomadic people, unused to living and managing a settled lifestyle, these Muslims (in addition to those already resident in China) quickly rose to positions of power; the Yuan founder, Kublai Khan (r.1260-1294), was unwilling to trust China's native Han population, who resented the rule of a non-Chinese dynasty. $\mathrm{He}$ therefore tasked the Muslims with governing his new empire. Indeed, the Yuan shi (The Imperial Records of the Yuan Dynasty) provides the details of numerous high-ranking Muslim officials, including Kublai Khan's chief minister (a man named Ahmad) and several important military figures. ${ }^{10}$ It was also during this period that Muslims were granted a monopoly over China's foreign trade, giving them access to great wealth. ${ }^{11}$

Although modern scholars consider these Yuan-period developments to be the highpoint in Chinese Muslim affairs, the community also undoubtedly remained significant during the subsequent Ming dynasty (1368-1644). ${ }^{12}$ In particular, it was during this period that the community's distinctively Sinicised identity emerged. ${ }^{13}$ Despite some limited evidence for Sinicisation amongst pre-Yuan and (especially) Yuan-period Chinese Muslims, it is only with the Ming, and their drive to assimilate China's non-Han minorities after the trauma of the Yuan dynasty, that a substantially Sinicised Muslim (or Hui) identity appeared..$^{14}$ By the mid-seventeenth century, therefore, China's Muslims spoke Chinese, wore Chinese clothing and observed Chinese customs. Because of (in some cases centuries of) intermarriage, they also appeared physically identical to the Han. ${ }^{15}$ None of this, however, necessarily entailed a loss of Islamic identity: even though a Ming-period ban on foreign travel resulted in a degree of isolation from the wider Islamic world, ${ }^{16}$ the Hui actively maintained a Hanafî-based form of Islam (often termed gedimu, from the Arabic qadìm, meaning 'old'), simply colouring it with traditional Chinese culture. ${ }^{17}$ From the seventeenth century onwards, this brand of Islam was further supplemented by various Sufi tarīqa - in particular, the Qādiriyya, Naqshbandiyya and Kubrawiyya. ${ }^{18}$

By the end of the Ming dynasty and beginning of the subsequent Qing dynasty (1644-1912), this Hui brand of Islam was reaching its apogee. Although no longer politically significant, the Hui remained culturally and intellectually dynamic, with their activities during this transition period ultimately giving rise to the Hān Kitāb tradition. The latter is therefore the product of a long-standing, mainly Persian-descended Muslim community that, over the course of many centuries, adopted numerous facets of Chinese culture and, to a degree, became isolated from other Muslim groups. The community did not, however, lose its commitment to its Islamic heritage. As we shall see, the resulting dual ChineseIslamic identity sits at the heart of the Hān Kitāb. 


\section{Wang Daiyu: The Birth of a Tradition}

Our first scholar, Wang Daiyu (ca.1580-ca.1658), also known as Zhenhui Laoren (The True Old Man of Islam), was born in Nanjing. ${ }^{19}$ In the introduction to his Zhengiao zhenquan (A True Commentary on the True Religion), Wang Daiyu tells us that his ancestor was an astronomer from Arabia who, after arriving in China as a diplomat during the reign of the Hongwu Emperor (r.1368-1398), demonstrated himself capable of correcting certain mistakes in the Chinese calendar. As a result, Hongwu allowed him to remain in China, giving him an official position in the Imperial Bureau of Astronomy and a house in Nanjing (then the capital). ${ }^{20}$ Writing nearly three hundred years later, Wang Daiyu claimed that, although his family was now, "thoroughly settled down [in China]," they had not become "forgetful of our origins."21 As such, while still young Wang Daiyu received a traditional Islamic education, learning both Persian and Arabic (the ancestral languages of the Hui). He also obtained a thorough grounding in all the major Islamic religious sciences, in addition to Sufism. ${ }^{22}$

From this starting point, Wang Daiyu would eventually become a renowned Islamic scholar and one of the earliest of the Hān Kitāb writers, with his first text appearing in $1642 .{ }^{23}$ In all, he would produce four important Hān Kitāb texts, both in Nanjing and Beijing, where he moved in 1645 after Nanjing's fall to the Qing. ${ }^{24}$ His first, however, the Zhengjiao zhenquan, remains his most influential. Essentially an explanation of Islam's teachings about God, the universe and the human soul, it takes the unusual step of systematically positioning Islamic teachings within the broader context of Chinese thought - in particular, NeoConfucianism..$^{25}$ To demonstrate this, however, and simultaneously provide an idea of its significance, it is first necessary to say something about NeoConfucianism as a worldview.

'Neo-Confucianism' is a modern term used to describe a post-tenth-century revival in Confucianism, the traditional Chinese philosophical school named after its founder, Confucius (also known as Kongzi, 551-479BCE). ${ }^{26}$ Although ultimately a very diverse school, Neo-Confucianism stems primarily from the work of just two thinkers: Zhou Dunyi (1017-1073) and Zhu Xi (1130-1200). ${ }^{27}$ As such, Zhu Xi founded the Cheng-Zhu School, Neo-Confucianism's dominant intellectual tradition right up until the nineteenth century. As a result, he is often described as the architect of Neo-Confucianism. Zhu Xi himself, however, attributed this role to Zhou Dunyi, whom he called the first true Confucian Sage since Mencius (Confucius's famous disciple, active in the fourth century BCE).$^{28}$ Indeed, Zhu Xi's work is primarily a commentary on Zhou Dunyi's Taijitu shuo (An Explanation of the Diagram of the Great Ultimate). Consequently, this text (or more accurately, Zhu Xi's interpretation of it) represents the cornerstone of 
Neo-Confucian thought. ${ }^{29}$ When generalising about the tradition's cosmology, it is therefore an appropriate starting point.

According to the Taijitu shuo, at the heart of all creation, as the source of all being and the root of all morality, lie two joint concepts: the Great Ultimate (taiji, a concept originating with the I Ching, China's oldest Classic, traditionally attributed to Confucius) and the Non-Ultimate (or the Ultimate Non-Being, wuji, a concept from the Dao De Jing, attributed to the sage Laozi, usually dated to the sixth century BCE). ${ }^{30}$ Although Zhou Danyi is vague about the precise nature of the Non-Ultimate and its relationship to the Great Ultimate, the following can be pieced together. The Non-Ultimate is reality situated beyond being and beyond conceptualisation; it has no attributes and cannot be named. The Great Ultimate, however, is pure undifferentiated being, from which the roots of all manifest reality stem. Together, these two concepts constitute a single reality and give rise to the universe through vital energy ( $q i)$, as differentiated into the two cosmic forces, yin and yang. ${ }^{31}$ Additionally, they are also the source of all Principle (li), or universal justice. Principle, which is self-evident and self-sufficient in itself, stretches everywhere and governs all things. Possessed by everything, Principle is universal truth, universal order and universal law. It is "that which is forever unchanging" ${ }^{\prime 2}$ and, ultimately, the road back to the Great Ultimate and NonUltimate. With the exception of humanity, all created objects have no choice but to conform to the requirements of Principle, as that which describes their correct nature. Humanity, however, has free-will. This means it can choose to ignore Principle, although doing so results in a need to purify humanity's actions. ${ }^{33}$ In this regard, Zhou Dunyi's Taijitu shuo contains a reference to the Human Ultimate (renji). Referring primarily to the Sages, the Human Ultimate is the man in whom Principle is fulfilled - the man who settles all affairs "by the mean [i.e. the middle], truth, humanity and righteousness, taking stillness as chief." ${ }^{\prime 34}$ Through him, the rest of humanity's purification is achieved.

This very briefly summarises Neo-Confucian cosmology. Wang Daiyu, however, utilised it to express Islam: he recast the Non-Ultimate as Allah's Divine Essence, or that which cannot be designated by name or attribute, and the Great Ultimate as the Divinity of Allah, or those specific and discernible Divine attributes which gave rise to the universe. Regarding the act of creation, Wang Daiyu - and in a manner reminiscent of medieval Muslim philosophers and their use of Neo-Platonic thought ${ }^{35}$ - fully appropriated the Neo-Confucian concepts of vital energy and yin and yang; observing that the Qur'an does not specify a precise mechanism for creation, Wang Daiyu saw no issue with accepting these concepts as valid.

Turning to Wang Daiyu's treatment of Principle, although this cannot be considered 'revealed law', Wang Daiyu saw it as equivalent to the values 
underlying sharî'a, itself also an expression of universal order. ${ }^{36}$ With regard to the Human Ultimate, Wang Daiyu equated this with Islam's doctrine of the Perfect Man (al-Insān al-Kāmil), as first espoused by Ibn 'Arabī (1165-1240) and embodied in the Prophet Muhammad. In this regard, Wang Daiyu highlighted each tradition's assertion that the Human Ultimate/Perfect Man is the fulfilment (or embodiment) of Principle/sharì'a, with his ability to perform this task resting in the purity of his heart. For each tradition, all good therefore depends on the presence of a sound and clean heart. ${ }^{37}$

But, if this summarises the essence of Wang Daiyu's work the question remains, why did he choose to express Islam in Neo-Confucian terms? Many modern commentators have addressed this point, offering several explanations. Some, for example, have suggested that Wang Daiyu was deliberately (and rather cynically) attempting to make Muslims 'fit in' during the tumultuous years of the Ming-Qing transition, when anything foreign was viewed with suspicion. ${ }^{38}$ Others, however, such as Murata, have cited Wang Daiyu's complaint that, as a young man, he found it difficult to communicate with the educated Hui; his Islamic-based education had left his knowledge of Chinese limited. The Hui intelligentsia, however, as products of the Chinese education system, were far more at home with the Chinese idiom than with either Persian or Arabic. ${ }^{39}$ To rectify this problem, therefore, Murata highlights how, at age thirty, Wang Daiyu began educating himself in Chinese, via an intensive study of the Chinese Classics. ${ }^{40}$ As his mastery of the language grew, his Hān Kitāb texts naturally followed as an additional means of educating the Chinese-speaking Hui about Islam. As Murata points out, however, the decision to express Islam in written Chinese created a unique problem.

Written Chinese differs significantly from either Persian or Arabic. Unlike those two languages, Chinese is not written using a purely phonemic script (i.e. one designed to represent a spoken language's most significant sounds). ${ }^{41}$ Rather, the characters used to write Chinese are largely logographic. Based on two hundred and fourteen elements (often termed 'radicals'), the Chinese writing system is composed of more than nine thousand individual characters, predominantly intended to represent specific concepts. When these concepts relate to complex cosmological constructs, the relevant characters naturally draw on (and are therefore unintelligible without) China's rich Confucian-DaoistBuddhist heritage. As a result, however, these characters are not necessarily appropriate for conveying Islamic cosmology. Moreover, and as Murata notes, although Chinese characters also have sound-associations, transliteration is neither easy nor desirable: for a Chinese-speaker, the specific concepts tied to each character turn any attempt at transliteration into a curious mishmash of meaning, rendering any text potentially unintelligible. ${ }^{42}$ When writing about 
Islam in Chinese, therefore, Wang Daiyu found himself with a clear problem: how to express Islam in the language of another intellectual tradition. Murata suggests that the Zhengjiao zhenquan's blending of Neo-Confucian and Islamic cosmologies is his pragmatic solution to this issue.

Although the above does convincingly demonstrate a linguistic imperative behind Wang Daiyu's work, whether it is sufficient to entirely explain his thought is unclear. For example, it is also noteworthy that Wang Daiyu frequently uses the Chinese word sheng (sage or saint) to describe Muhammad. ${ }^{43}$ In Chinese, sheng typically refers to one of the Chinese sages, particularly Confucius. By applying it to Muhammad, however, Wang Daiyu was essentially equating it with the Arabic nabi (prophet). By implication, therefore, and in the context of Wang Daiyu's overall discussion, he would seem to be according prophetic status to Confucius. Indeed, this should not be surprising: according to the Qur'an, every nation prior to Muhammad received a prophet (see 10:47 and 35:24), each of whom carried the same basic message - a warning to obey God and eschew evil (see 16:36). Moreover, in süra 30 (al-Rūm), àya 30, the Qur'an states:

Then set your face towards religion inclining to truth, adhering to the nature [fitra] made by Allah in which he has made all men. There is no change in the creation of Allah; that is the correct religion, but most of the people do not know. ${ }^{44}$

On the basis of this verse, 'ulamā' have argued that fitra, as humanity's original state of creation, encapsulates an innate inclination towards tawhìd (or a belief in the Oneness of God) ${ }^{45}$ By implication, therefore, the "correct religion" mentioned in this verse must, because it corresponds to fitra, have tawhìd at its core. The 'ulam $\bar{a}$ ' name this religion din al-fitra (or the 'natural/original religion'). Although only perfected in the Qur'an, the 'ulam $\bar{a}$ ' argue this basic message was also enshrined in every religion established by every prophet before Muhammad. ${ }^{46}$ The persistence of Wang Daiyu's argument, coupled with the depth of his Islamic learning, suggests that he believed he had found such a core in Confucius's work. In other words, to argue that Wang Daiyu simply wrote for the sake of expediency is perhaps overly teleological, wrongly choosing to define his work only in terms of what it accomplished (i.e. Islam's greater integration into Chinese culture or the communication of Islamic knowledge to Chinesespeaking Hui). Rather, it should not be understated that, firstly, a belief in preIslamic prophets is integral to the Qur'anic text and, secondly, the concept of din al-fitra was well-established amongst Islamic scholar by Wang Daiyu's time. In his Zhengjiao zhenquan, Wang Daiyu (as a Muslim) was simply giving both concepts full expression. 


\section{Ma Zhu: Muslims under Non-Muslim Rule}

Our next figure is Ma Zhu (ca.1640-ca.1710), also known as Yūsuf. ${ }^{47}$ Born in Baoshan County, Yunnan, he came from a very prominent (but highly Sinicised) Hui family: his ancestors claimed descent from Sayyid Ajjal, the first (Muslim) Yuan governor of Yunnan, whose descendants continued to rule the province for many subsequent generations ${ }^{48}$ Politically and culturally, therefore, Ma Zhu came from Yunnan's most important family. ${ }^{49}$ His father, however, Ma Shikong, was a tongsheng (First Degree holder) and scholar of the Chinese Classics. In this capacity, he worked as a local teacher, training students for the Classics examinations. ${ }^{50}$ Although he died when Ma Zhu was only seven, Ma Zhu's mother encouraged her son to continue in his father's footsteps. Ma Zhu therefore enrolled in the Chinese education system and, at age sixteen (i.e. in ca.1656), passed the provincial examinations to become a xiucai (or shengyuan, a Second Degree holder, one step above his father). ${ }^{51}$ Subsequently, he gained a minor bureaucratic position with the remnants of the Ming court, which had been forced to flee to Yunnan by the advancing Qing armies. Ma Zhu continued to serve the last Ming emperor, Yongli (r.1644-62), until the latter's death. ${ }^{52}$

Due to his Chinese educational background, Ma Zhu received no formal Islamic education while still young. ${ }^{53}$ When he did eventually begin exploring his religion, however, he quickly showed himself to be an able student, publishing his first Hān Kitāb text in 1659, at the age of just nineteen. ${ }^{54}$ After 1662, and the death of the last Ming Emperor, he continued his learning and writing activities while working as a teacher in Yunnan..$^{55}$ By 1665 , he was well-known throughout the province as a learned scholar. ${ }^{56}$ In 1669 , however, he moved to Beijing, to a teaching post at the Imperial Academy (the Guozijian). While there, he continued learning about Islam, becoming particularly enamoured with Wang Daiyu's work, which he likened to "a dose of strong medicine to save a sick man." ${ }^{57}$

Indeed, Ma Zhu shared Wang Daiyu's desire to help Chinese-speaking Hui access their religion more easily. ${ }^{58}$ With this aim in mind, in 1684 Ma Zhu completed the first draft of what would become his masterpiece - the voluminous Qingzhen zhinan (or al-Murshid ilā 'Ulüm al-Isläm, The Guide to the Sciences of Islam). Indeed, of all Hān Kitāb texts, this is arguably the most well-read and well-respected. ${ }^{59}$ Essentially a complete explanation and justification of Islam, it was produced both for those Chinese-speaking members of the Hui who had little understanding of Islam, and those non-Muslim Chinese who were interested in learning more about the religion. After completing the first draft, Ma Zhu took the text over the length and breadth of China, showing it to every famous ahong (Imam) and scholar he could find (including Liu Sanjie, Liu Zhi's father, see below) ${ }^{60}$ Each commented on it and suggested revisions when appropriate; Ma 
Zhu subsequently took all these on board, taking another fifteen years to revise the text (finally published around the time of his death, in 1710). ${ }^{61}$

Overall, Ma Zhu's magnum opus shares much in common with Wang Daiyu's work, differing only on points of detail. For example, while largely maintaining Wang Daiyu's cosmology, Ma Zhu argues that the Great Ultimate and the NonUltimate are not in fact Allah, but that Allah sits behind them:

The Non-Ultimate is not God [zhenzhu], but without it God's initial commandment could not be manifest. The Great Ultimate is not God, but without it God's vast power could not be manifest. ${ }^{62}$

Largely, however, Ma Zhu's discussion of Islamic and Neo-Confucian thought follows Wang Daiyu. In particular, the historical section of his text, entitled Qing bao biao, also describes Muhammad as a Sage (sheng), while simultaneously calling him the "culmination of the achievements of the ten thousand generations of former [Chinese] sages." ${ }^{63}$ Once again, this appears to equate Chinese sagehood with Islamic prophethood, with all that entails.

Ultimately, however, the importance of Ma Zhu's work lies not in its cosmological outlook, but in its political ramifications. Upon completing the Qingzhen zhinan, Ma Zhu tried to (unsuccessfully) submit it to the Kangxi Emperor (r.1661-1722). As part of this process, Ma Zhu wrote a memorial to the throne, drawing attention to (what Ma Zhu saw as) the equivalency between the Islamic and Neo-Confucian moral orders (that is, between shar $\bar{\imath}$ ' $a$ and principle). Ultimately, Ma Zhu argued, Islam could help Neo-Confucianism complete its civilising mission (i.e. the fulfilment of Principle) ${ }^{64}$ Politically, however, this is significant: as J. Frankel highlights, it entails the development of a dual allegiance.

Because Neo-Confucianism held the Emperor - as the Son of Heaven and possessor of the Mandate of Heaven - to be the instrument of Principle's enforcement, Ma Zhu's memorial essentially argued that Muslims could pledge their political loyalty to the Chinese Emperor. Indeed, provided the Emperor abided by the principles of justice shared by Islam and Neo-Confucianism, the Hui were obliged to pay allegiance to him. The Neo-Confucian social hierarchy, integral to maintaining a Neo-Confucian sense of moral order, was inseparable from being a good Muslim. This supposition, however, demonstrates Ma Zhu's rejection of the juristically constructed, mutually opposed and opposing realms of Dār al-Islām (Abode of Islam) and Dār al-Harb (Abode of War, traditionally used to describe non-Islamic nations). Although neither of these concepts has any scriptural basis, some Muslims have used them to argue for a political separation between Muslims and non-Muslims. Because Ma Zhu recognised a common core to both Islam and Neo-Confucianism, however, he saw no contradiction in asking the Muslim Hui to swear allegiance to the non-Muslim Emperor. ${ }^{65}$ 
As with Wang Daiyu, some modern commentators have argued that this aspect of Ma Zhu's work is rooted in a cynical need to present the Hui as a neutral, nonthreatening presence within China ${ }^{66}$ It should be emphasised, however, that Ma Zhu's logic is entirely consistent: the political implications of his argument form part of a coherent progression, beginning with his identification of a common core to both Islam and Neo-Confucianism. As with Wang Daiyu, it would seem a potential distortion to dismiss his work as opportunistic; his intellectual integrity belies a more honest intention.

\section{Liu Zhi: The Perfection of a Tradition}

Our last figure, Liu Zhi (ca.1670-1739), also known as Liu Jia Lian, was born in Nanjing. ${ }^{67}$ Little is known about his background and personal life. His education, however, began in his native city, in a school established by the leading Hui educational master, Yuan Shengzhi. A relative of Liu Zhi's father, Liu Sanjie (also known as Liu Hanying), Yuan Shengzhi was a disciple of the great Chinese Muslim educational reformer, Hu Dengzhou (also known as either Puchao or Muḥammad Ibrāhīm Ilyās, d.1597). Often called taishi (Great Teacher), during his lifetime Hu Dengzhou propagated a new brand of Chinese-language-based Islamic learning. By the seventeenth century, this had spread to several important Hui centres, including Xian, Jining, Kaifeng and Nanjing. ${ }^{68}$ Liu Zhi's inclusion in this system, however, exposed him to Chinese-language Islam from early on; for the young Liu Zhi, the principles of the Hān Kitāb were therefore already familiar. Moreover, as a boy Liu Zhi may also have met Ma Zhu: Liu Sanjie is listed as one of the commentators on the Qingzhen zhinan. ${ }^{69}$ By the end of his lifetime, however, Liu Zhi's reputation would far outstrip that of Ma Zhu; his eventual breadth of knowledge would make him the epitome of the Hān Kitāb tradition.

Liu Zhi's path to scholarly recognition began, however, at age fifteen. Seeking to build on his Chinese-language Islamic education, Liu Zhi undertook an eight-year exploration of the traditional Chinese classics and histories, followed by a further six years studying Arabic and Islamic texts (all in their original language). He then moved on to Buddhism (three years) and Daoism (one year), before rounding off his education with one hundred and thirty-seven European texts introduced into seventeenth-century China by the Jesuits. ${ }^{70}$ Exposure to this programme of study gave Liu Zhi an extremely broad intellectual foundation; not only was he fully versed in the Islamic tradition, but equally well qualified to be a member of the Chinese literati. This joint identity, however, led him to an important realisation: utilising the breadth of his knowledge, Liu Zhi developed a firm conviction that Islamic thought could not be inward looking. In his own words: 
The sacred book is the sacred book of Islam, but Principle is the same Principle which exists everywhere under Heaven. ${ }^{71}$

In other words, although the Qur'an (as the sacred book) represented the perfection of Principle, just like Wang Daiyu and Ma Zhu before him, Liu Zhi argued that Neo-Confucianism also expressed the same universal truth, Confucius having been a bearer of divine inspiration. On this basis, Liu Zhi advocated reaching out to the Neo-Confucian establishment in order to reconcile it to Islam. ${ }^{72}$

With this imperative in mind, after completing his studies Liu Zhi took up residence at the foot of Nanjing's Qingliangshan Mountain, in a studio called Saoyelou (House of Sweeping Leaves). There he began translating Arabic texts into Chinese. In addition, however, he also composed several hundred original Chinese-language manuscripts, all of which sought to relate Islam to Neo-Confucianism. Although only one tenth of these were ever published, three became very influential: the Tianfang xingli (The Principles of Islam, published in 1704), ${ }^{73}$ the Tianfang dianli (The Rules and Proprieties of Islam, 1710) ${ }^{74}$ and the Tianfang zhisheng shilu (The Record of the Prophet of Islam, 1724). ${ }^{75}$ The first of these focused on ușül al-dìn (specifically, on tawhìd, nubuwwa and $m a ' \bar{a} d$ ), the second on furu' 'al-dīn (the branches and applications of faith), and the last on a biography of the Prophet (based primarily on a Persian translation of the work of Muhammad ibn Mas' '̄̄d Kāzarūn̄̄, d.1357). ${ }^{76}$ Significantly, Liu Zhi intended these three texts to be read together; through them he was attempting to describe the three stages of Sufism - namely, the sharì'a (i.e. the way), the tariqa (the teachings) and the haqiqa (the Reality of God, as embodied in the example of the Prophet). By utilising this threefold division, however, Liu Zhi was also paralleling traditional Chinese thought, where discussions begin with the dao (theoretical underpinning), before moving on to the jiao (the concrete, relative and practical vehicle of the dao) and then the Sage who acted as the bridge between these points. ${ }^{77}$ As such, and in a more integral manner than his predecessors, Liu Zhi was attempting to express Islam within a traditional Chinese intellectual framework.

Perhaps Liu Zhi's most distinctive innovation, however, was his unconventional approach to furū' al-dīn. Most Islamic texts under this heading are works of fiqh (jurisprudence), designed to illustrate methods of $i b \bar{a} d a$ (or ritual, such as prayer) and adab (etiquette). Liu Zhi's Tianfang dianli, however, is centred on the theory underpinning Islamic rituals. In other words, Liu Zhi was not interested in describing how (for example) Muslims pray (and, indeed, his text provides only a very loose guide on that matter), but with establishing why they pray. In part, this reflects Liu Zhi's perception of both $i b \bar{a} d a$ and $a d a b$ as expressions of Principle, or universal justice, order and law. ${ }^{78}$ As manifestations 
of morality and social harmony, Liu Zhi argued that these rituals must first be fully understood before they can be practiced; only by emphasising the meaning of ' $i b \bar{a} d a$ and $a d a b$ can Muslims effectively implement them. Liu Zhi therefore distanced himself from dry ritualism, instead preferring to accentuate the inner spiritual meaning of Islam. In this regard, his work again falls into the realm of Sufism. Indeed, of the sixty-six Islamic sources Liu Zhi referenced across all three of his books, many are Ishrāqiyya (or Illuminationist) Sufi texts from the Central Asian Kubrawiyya tarīqa. Thus, the two works Liu Zhi cites the most are both Kubrawiyya: the Mirșād al- 'ibād min al-mabda' ila'l-ma 'âd of Najm al-Dīn Rāzī (d.1247) and the Maqsad-i aqsā of 'Azīz Nasafì (d.ca.1300). ${ }^{79}$

By delving into these theological matters, however, Liu Zhi aimed to further demonstrate the numerous parallels between Islamic and Neo-Confucian thought. Just as with Wang Daiyu and Ma Zhu before him, Liu Zhi peppered his explanations of Islam with Neo-Confucian terms, to help bridge the gap between the two traditions and merge their ideologies into a single whole. Indeed, Liu Zhi's efforts in this regard did not go unnoticed: his biography of the Prophet was honoured with a preface by the Vice-Minister of the Board of Ritual, who wrote:

The ancient Confucian doctrine has been undermined at different times by Buddhists and Daoists...now, however, in this book of Liu Zhi we see once more the way of the ancient sages, Yao and Shun, King Wen and King $\mathrm{Wu}$ and Confucius. Thus, although this book explains Islam, in truth it illuminates our Confucianism. ${ }^{80}$

Likewise, the Vice-Minister of the Board of War contributed a preface to Liu Zhi's Tianfang dianli, stating that the minister, while discussing Islam with Liu Zhi, had come to the realisation that it upheld traditional Neo-Confucian values, such as loyalty to the Sovereign, filial piety and brotherly love. Indeed, the Tianfang dianli was later included in the Siku quanshu (The Complete Library of Four Sections), the largest compilation of Chinese books in history (initiated by the Qianlong Emperor in 1772). Inclusion in this Imperial project gave Liu Zhi's text official Neo-Confucian recognition, a distinction no other Hān Kitāb text ever received. ${ }^{81}$

\section{Concluding Remarks and Recommendations: The Hān Kitāb and Wasatiyya}

To summarise our discussion so far, from the mid-seventeenth century onwards, China became host to a distinctive brand of Islam called the Hān Kitāb. Partially inspired by a unique set of cultural and linguistic circumstances, ideologically the Hān Kitāb came to rest on the Islamic concept of din al-fitra (the 'original 
religion'). Evolved from Islam's key texts, the concept of din al-fitra denotes the "correct religion" ordained by God (see Qur'an 30:30). Although only perfected in the Qur'an, this "correct religion" also constituted the core of several earlier messages, sent to the peoples of all nations by a series of (usually unidentified) prophets. Some of China's Sinicised Muslims (known as the Hui), informed by a close analysis of Neo-Confucian thought, argued that Confucius had been a bearer of din al-fitra, with the Chinese concept of sagehood essentially being equivalent to the Islamic concept of prophethood.

On this foundation, our three key thinkers attributed the commonalities between Neo-Confucianism and Islam to a common core of din al-fitra. As such, the earliest surviving Hān Kitāb writer, Wang Daiyu, and while equating sagehood with prophethood, saw no issue with associating the Neo-Confucian concepts of the Great Ultimate and the Non-Ultimate with the Islamic Allah, or with seeing the Human Ultimate as the equivalent of the Islamic Perfect Man. These concepts, he believed, were simply counterparts of each other; at the core of each tradition beat the same heart.

Turning to the second of our thinkers, Ma Zhu, while building on Wang Daiyu's work, he argued that the existence of a common core to both NeoConfucianism and Islam made it incumbent on the Hui to pledge their allegiance to the non-Muslim Chinese Emperor. In other words, because the Emperor was charged with enforcing Principle, seen by Ma Zhu as embodying the same values as sharî' a, so long as the Emperor continued to uphold those basic moral values, Muslims had a religious duty to support him. This argument, however, is highly significant. Although there has never been any consensus about whether Muslims can live under non-Muslim rule (let alone pledge their loyalty to a non-Muslim ruler), with some scholars openly supporting the possibility ${ }^{82}$ and others firmly rejecting it, ${ }^{83}$ contemporary expressions of Islamic extremism often finding root in Salafî thought - have tended to utilise (somewhat selective interpretations of) Ibn Taymiyya (d.1328) to vehemently oppose any and all Muslim settlement in non-Muslim lands. ${ }^{84}$ For them, the principle of al-wala ${ }^{\text {, }}$ wa'l-barā' (loyalty [to Muslims] and disavowal [from non-Muslims]) is paramount. ${ }^{85}$ In Ma Zhu, however, we have the opposite perspective: via the concept of din al-fitra, Ma Zhu argued that the equivalency between NeoConfucian and Islamic moral principles made it mandatory for the Hui to support any Chinese Emperor who upheld those values. The contrary position - to disobey a just ruler and sow discord in the land - would oppose both sharī'a and Neo-Confucian Principle. In this regard, Ma Zhu's work conforms to the ideals of the modern Islamic discipline, fiqh al-aqalliyāt (the jurisprudence of minorities). Dealing specifically with the issue of Muslims living in non-Muslim lands, fiqh al-aqalliyāt also argues that Muslims have an ethical obligation to 
live as law-abiding citizens in non-Muslim lands, provided the rulers of those lands uphold the basic moral principles of Islam. ${ }^{86}$

Turning to the last of our thinkers, Liu Zhi, his Tianfang dianli took an innovative approach to furū' al-dīn. Choosing to discuss 'ibāda and adab in relation to their inner meaning rather than just their outward appearance, Liu Zhi labelled them as expressions of moral order and social harmony (the NeoConfucian Principle). On this basis, Liu Zhi argued that both 'ibāda and adab must be fully understood before either can be effectively practiced. Just like Ma Zhu's work, this Sufi-orientated approach to furū' al-din has contemporary significance: Salafi-inspired interpretations of Islam often equate the letter of the Islamic texts (i.e. what is evident, al-zāhir) with their meaning (or what is hidden, $a l-b a \overline{a t i n}$ ). As a result, Salafì practitioners tend towards literalism; their 'ibāda and $a d a b$ stress outward conformity to prescribed ritual norms, while neglecting the meanings which may underpin those practices ${ }^{87}$ Like Ma Zhu, both Liu Zhi and the Sufi interpretations which inspired him provide a welcome corrective to this approach.

This and the above reference to Salafî thought, however, suggests a possibility. Although contemporary exponents of Islamic reform ('ișlạh) are members of an extremely diverse, heterogeneous and often divided group, in general they share a common concern: to combat extreme, often violent Salafî interpretations of Islam. Could, therefore, the Hān Kitāb contribute to this endeavour, to the principles of Islamic reform?

To date, the most compelling attempts to counter Salafi ideology have utilised a conceptual framework based on the principle of wasatiyya (moderation). According to one of its most prominent advocates, Mohammad Hashim Kamali, wasatiyya is the opting for a 'middle way', or the avoiding of extremities. ${ }^{88}$ Although a relatively recent theme in Islamic scholarship (Kamali dates its appearance to the early twentieth century, with figures like Rashīd Riḍa and Hassan al-Bannā), it is clearly rooted in Qur'an and Sunna. ${ }^{89}$ Significantly, therefore, many aspects of the Hān Kitāb conform to wasatiyya. For example, although the $H \bar{a} n$ Kitāb tradition clearly rejects strict and inflexible forms of Islamic practice, neither does it jettison all standard Islamic forms of worship. Rather, it advocates a 'middle way': Liu Zhi's Tianfang dianli, although focusing on meaning and not form, never denies the importance of practice. Likewise, Ma Zhu advocates neither a rejection of all political association with non-Muslims nor a pledging of loyalty to a non-Muslim ruler regardless of the latter's behaviour. Instead, he advocates the middle path of accepting non-Muslim rule provided it conforms to the key principles of Islam.

In addition to its principles of moderation, however, it is also highly significant that the Hān Kitāb's intellectual cornerstone, din al-fitra, is an entirely Islamic concept. In other words, the Hān Kitāb's call to recognise truth in other traditions 
(with all that entails) is not a result of syncretism, hybridity, secular borrowings, or anything else which could be construed as a dilution of Islamic belief. Rather, the Hān Kitāa's ecumenical stance derives entirely from Islam itself. Likewise, the emphasis on interpreting and not just following 'ibāda and adab is Sufiinspired, and therefore also inherently Islamic. These points are important: if any programme of Islamic reform is to be effective, it must be seen to originate from within Islam itself. Otherwise, its Islamic identity and (therefore) credibility will be severely compromised. It is therefore significant that the Hān Kitāb qualifies as an entirely Islamic tradition.

Ultimately, the Hān Kitāb is an authentic Islamic tradition, embodying many of the principles of moderation (wasatiyya). Given the concerns currently facing Islam, our paper would like to recommend that this Chinese Muslim tradition be examined in more depth, to determine precisely how it could contribute to modern 'ișlāh paradigms. Few (if any) Muslim scholars are currently aware of the Hān Kitāb; the pressing need to develop a moderate Islamic stance capable of tackling extreme Salafĩ thought suggests that this needs to change. Additionally, the Hān Kitāb's unique blend of Islamic and Neo-Confucian thought may also have policy implications for the Muslim majority countries of Southeast Asia. Since independence, these countries (and especially Malaysia) have experienced an acute need to effectively integrate their non-Muslim Han minorities. Just as Wang Daiyu, Ma Zhu and Liu Zhi may have utilised their ideas to facilitate Hui acculturation in China, perhaps Malaysia and its neighbours could reverse the paradigm to utilise Hān Kitāb ideology to acculturate their non-Muslim Han minorities. Certainly, the Hān Kitāb's emphasis on the commonalities between Islam and Neo-Confucianism could help bridge the cultural gap between Southeast Asia's Muslim and Chinese populations.

\section{Notes}

* Alexander Wain obtained his DPhil (PhD) from the University of Oxford in 2015. A specialist in the history of Islam in Southeast Asia and China, his DPhil research focused on the possible role of Chinese Muslims in the conversion of the Nusantara (Maritime Southeast Asia) between the thirteenth and sixteenth centuries. Currently, he is Research Fellow at The International Institute for Advanced Islamic Studies (IAIS) Malaysia. At IAIS, Alexander is working on a critical outline of the Chinese Islamic philosophical school known as the Hān Kitāb. Drawing attention to the school's broad intellectual framework - in particular, its willingness to utilise both Islamic and non-Islamic texts, to marry Islamic and Neo-Confucian thought - Alexander aims to assess whether the Hān Kitāb's inherent inclusivity can contribute towards the principles of reform (ișlāh and moderation (wasatiyyah) in modern-day Islam. Email: alex@iais.org.my. 
1. The term 'Hui' first appeared during either the late Yuan dynasty (1271-1368) or the early Ming dynasty (1368-1644) and is used here to refer to China's Sinicised Muslim population. It is not, however, used to refer to China's preYuan-period Muslims, many of whom were not Sinicised. See Raphael Israeli, Islam in China: Religion, Ethnicity, Culture, and Politics (Oxford: Lexington Books, 2002), 99. It should also be noted that the Hui are distinct from China's Uyghur population, which is Turkic.

2. Syed Farid Alatas, An Islamic Perspective on the Commitment to Inter-Religious Dialogue (Kuala Lumpur: IAIS, 2008), 5-6.

3. Sachiko Murata, 'The Resources of Ecumenical Thought in Chinese Islam,' Forum Bosnae 38 (2006): 42.

4. The earliest surviving Chinese Muslim origin myths actually date from the late Yuan dynasty. One constitutes part of a 1348 inscription at the Dingzhou mosque, Hebei province, while two very similar inscriptions (both dated 1350) appear at the Qingiing Si mosque in Quanzhou (Fujian province) and the Huaisheng Si mosque in Guangzhou (Guangdong province). Although all three also name $\mathrm{Sa}^{\prime} \mathrm{d}$ ibn Abī Waqqās as the community's founding father, they lack the detail of the Huihui Yuanlai, see Haiyun Ma, 'The Mythology of Prophet's Ambassadors in China: Histories of Sa'd Waqqas and Gess in Chinese Sources,' Journal of Muslim Minority Affairs 25, no. 3 (2006): 446-7.

5. According to the text, Sa'd ibn Abī Waqqās travelled to China as a diplomat. His visit was apparently occasioned by a dream in which the Tang Dynasty Emperor, Gaozong (r.649-683), saw a turbaned man chasing a devil around the palace. Gaozong's Interpreter of Dreams construed the devil as an ill-omen, but stated that "the turbanned [sic] man is a Huihui [Muslim] from the west. In Arabia is a Muslim king of great virtue. A great sage is born, with favourable omens." To avoid the ill-fortune portended by the devil, therefore, Gaozong reputedly despatched an ambassador to Arabia, to ask the great sage (i.e. Muhammad) for help. Sa‘d ibn Abī Waqqās was supposedly sent as a result, see Jonathan N. Lipman, Familiar Strangers: A History of Muslims in Northwest China (Seattle, WA: University of Washington Press, 1997), 24. The Huihui Yuanlai also claims that $\mathrm{Sa}$ 'd ibn Abī Waqqās was accompanied by two additional (but unidentified) Muslims, Gai Si and Wu Wai Si. These two, however, died before reaching the imperial court. After meeting with Gaozong, Sa'd ibn Abī Waqqās was reputedly allowed to remain in China and establish the first mosque (the Huaisheng mosque, in Guangzhou), see Haiyun, 'Mythology of Prophet's Ambassadors' 446.

6. Hadi Hasan, A History of Persian Navigation (London: Methuen \& Co. Ltd., 1928), 27.

7. According to the prominent ninth- to tenth-century Arab geographical treatise, the Akhbär al-Sin wa 'l-Hind (Accounts of China and India), in 877/8 Guangzhou (then China's main port) housed a foreign population of 120,000 people, most of whom were Arabs, see James E. Montgomery and Tim Mackintosh-Smith Ed. and trans., Two Arabic Travel Books: Accounts of China and India by Abü Zayd al-Sìräfí and Mission to the Volga by Ahmad ibn Faḍlān (New York: New York University Press, 2014), 67-9. Another tenth-century Arab geographer, however, Abū al-Hasan al-Mas'ūdī (896-956), in his Murüj adh-dhahab wa ma'ädin aljawāhir (Meadows of Gold and Mines of Gems, written in ca.943) has 200,000 
people, cited in Ibid, 138.

8. Zvi Ben-Dor Benite, The Dao of Muhammad: A Cultural History of Muslims in Late Imperial China (Cambridge, MA: Harvard University Asia Center, 2005), 16-7.

9. Lipman, Familiar Strangers, 34.

10. Donald Daniel Leslie, Islam in Traditional China: A Short History to 1800 (Belconnen: Canberra College of Advanced Education, 1986), 98. In terms of military figures, the Yuan shi refers to a particularly important Yuan general, known in Chinese as either Saidianchi Zhansiding or just Wumar. This is the Central Asian prince, Sayyid Ajjal Shams al-Dīn 'Umar al-Bukhārī (1211-1279) who, after surrendering to the Mongols, became one of Kublai Khan's chief generals. In 1274, he was also tasked with conquering and pacifying China's Yunnan province, then an independent kingdom bordering on modern-day Vietnam, Laos, Thailand and Burma. Upon completing this mission, Sayyid Ajjal was appointed to Yunnan's governorship; under his and his descendants' leadership, the province became a largely Muslim enclave, see both Jianping Wang, 'Islam in Yunnan,' in Islam in China: Key Papers, vol. 1, ed. Michael Dillon (Folkestone: Global Oriental, 2009), 291 and Benite, Dao of Muhammad, 196-7.

11. Derek Thiam Soon Heng, Sino-Malay Trade and Diplomacy from the Tenth through the Fourteenth Century (Athens, OH: Ohio University Press, 2009), 65-6.

12. Indeed, the Hui maintain that their community actually peaked during the early Ming period: in addition to prominent Ming-period figures like Zheng He, the Hui also claim that the Ming founder, Zhu Yuanzhang (or the Hongwu Emperor), was a Muslim, see Hajji Yusuf Chang, 'The Hui (Muslim) Minority in China: An Historical Overview,' in Islam in China: Key Papers, vol. 1, ed. Michael Dillon (Folkestone: Global Oriental, 2009), 136. Although most scholars reject this assertion, Zhu Yuanzhang did undoubtedly have a close relationship with Islam: he ordered the construction of numerous mosques, both in Nanjing and in the southern provinces of Yunnan, Guangdong and Fujian; he reputedly composed an inscription praising the Prophet Muhammad (originally set up in an unspecified Nanjing mosque); and at least ten of his generals were supposedly Muslim (including Lan Yu, Chang Yuqun and Mu Ying), in addition to several important officials (including Hai Rui, Ma Wensheng, Ma Ziqiang and Li Zhi), see Lipman, Familiar Strangers, 39-40, Tan Ta Sen, Cheng Ho and Islam in Southeast Asia (Singapore: Institute of Southeast Asian Studies, 2010), 291, and Zvi Ben-Dor Benite, "“The Marrano Emperor": The Mysterious, Intimate Bond between Zhu Yuanzhang and his Muslims,' in Long Live the Emperor! Uses of the Ming Founder Across Six Centuries of East Asian History, ed. Sarah Schneewind (Minneapolis, MN: Society of Ming Studies, 2008), 278-9, 285-6.

13. Israeli, Islam in China, 99.

14. Lipman, Familiar Strangers, 39. Indications of pre-Ming-period Sinicisation can be found at the oldest surviving Muslim cemetery in Quanzhou, called Lingshan (Mountain of Souls). Preserving graves from the thirteenth century, this graveyard is aligned according to the principles of feng shui, see Chen DaSheng and Denys Lombard, 'Foreign Merchants in Maritime Trade in Quanzhou ("Zaitun"): Thirteenth and Fourteenth Centuries,' in Asian Merchants and Businessmen in the Indian Ocean and the China Sea, ed. Denys Lombard and 
Jean Aubin (Oxford: Oxford University Press, 2000), 22. Also, the late thirteenth century saw a number of mosques being built in a traditional Chinese temple style, including the Fonghuang mosque of Hangzhou (Zhejiang province), see Zhang Jing Qui, 'Mosques of Northern China,' MIMAR 3 (1982): 58 and Zhang Jing Qui, Islamic Architecture in China, available at: http://earp.cga.harvard. edu/files/basket/islamic_arch_china.pdf. (Accessed on: 07/12/2011).

15. Israeli, Islam in China, $\overline{1} 13$.

16. Hu Jichuang, A Concise History of Chinese Economic Thought (Beijing: Foreign Languages Press, 1988), 448.

17. Dru C. Gladney, Muslim Chinese: Ethnic Nationalism in the People's Republic (Cambridge, MA: Harvard University Press, 1996), 37.

18. Dru C. Gladney, Dislocating China: Reflections on Muslims, Minorities, and other Subaltern Groups (Chicago, IL: The University of Chicago Press, 2004), 128-30.

19. Sachiko Murata, Chinese Gleams of Sufi Light: Wang Tai-yu's Great Learning of the Pure and Real and Liu Chih's Displaying the Concealment of the Real Realm (Albany, NY: State University of New York Press, 2000), 19.

20. J. F. Ford, 'Some Chinese Muslims of the Seventeenth and Eighteenth Centuries,' Asian Affairs 5, no. 2 (1974): 145.

21. Ibid, 145 .

22. Murata, Chinese Gleams, 20. It is unknown which tarīqa Wang Daiyu may have belonged to.

23. Although Wang Daiyu is undoubtedly the earliest surviving Hān Kitāb writer, he is probably not the first. Liu Zhi, for example, mentions two earlier Hān Kitāb texts, neither of which have survived: the Qingzhen Jiaokao Xi of Zhang Xin (written in 1634) and the Chunshu (Huiji) Shii Ba of Zhan Yingpeng (1636), see Donald D. Leslie, Islamic Literature in Chinese, Late Ming and Early Ch'ing: Books, Authors and Associates (Canberra: Canberra College of Advanced Education, 1981), 21.

24. Murata, Chinese Gleams, 21.

25. Encyclopedia of Islam, $3^{\text {rd }}$ ed., s.v. 'Chinese Muslim Literature.'

26. Murata, 'Resources of Ecumenical Thought,' 44.

27. See Joseph A. Adler, 'Zhou Dunyi: The Metaphysics and Practice of Sagehood,' in Sources of Chinese Tradition, $2^{\text {nd }}$ ed., ed. Wm. Theodore de Bary and Irene Bloom (New York: Columbia University, 1999), Ch. 20.

28. Ibid.

29. Ibid.

30. Siu-chi Huang, Essentials of Neo-Confucianism: Eight Major Philosophers of the Song and Ming Periods (London: Greenwood Press, 1997), 22-4.

31. Murata, Chinese Gleams, 36-7.

32. Ibid, 36 .

33. Ibid, 37-8, 41-2.

34. Ibid, 48-9; Sachiko Murata, William C. Chittick and Tu Weiming, The Sage Learning of Liu Zhi: Islamic Thought in Confucian Terms (Cambridge, MA: Harvard University Press, 2009), 437-8.

35. See Alexander Wain, 'A Critical Study of Mabādi' ārā' ahl al-madīna al-fädila: The Role of Islam in the Philosophy of Abū Nașr al-Fārābī,' Journal of Islamic Philosophy 8 (2012): 45-78. 
36. Murata, Chinese Gleams, 48.

37. Ibid, 38 .

38. Although several modern texts express this opinion, Raphael Israeli is by far its most prominently advocate, see R. Israeli, 'China's Muslims,' in The World's Religions: Islam, ed. Peter Clarke (London: Routledge, 1990), 102-118.

39. Ford, 'Some Chinese Muslims,' 145.

40. Murata, Chinese Gleams, 20-1.

41. In addition to Murata's text, see Benite, Dao of Muhammad, 70.

42. See Murata, 'Resources of Ecumenical Thought,' 44-5.

43. Murata, Chinese Gleams, 48.

44. The essence of this verse is also encapsulated in a tradition attributed to Muhammad: "Abū Hureyra reported that the Prophet Muhammad said: 'No baby is born but upon fitra. It is his parents who make him a Jew or a Christian or a Polytheist"” (Muslim, Book 33, Hadith 6426).

45. Abu al-Fazl 'Izzati', Islam and Natural Law (London: ICAS Press, 2002), 62, 95.

46. The Islamic conception of prophecy is very expertly summarised by Kieko Obuse, 'The Muslim Doctrine of Prophethood in the Context of BuddhistMuslim Relations in Japan: Is the Buddha a Prophet?' The Muslim World 100 (2010): 215-7.

47. Ford, 'Some Chinese Muslims,' 148.

48. Lipman, Familiar Strangers, 79.

49. It would also make him a distant relative of the famous Chinese Admiral, Zheng $\mathrm{He}$, who, originally named $\mathrm{Ma} \mathrm{He}$, also claimed descent from Sayyid Ajjal, see Chang Kuei-sheng, 'Cheng Ho,' in Dictionary of Ming Biography 1368-1644: The Ming Biographical History Project of the Association for Asian Studies, vol. 1, Ed. L. Carrington Goodrich and Chaoying Fang (New York: Columbia University Press, 1976), 194-200.

50. Benite, Dao of Muhammad, 137.

51. Lipman, Familiar Strangers, 79.

52. Ford, 'Some Chinese Muslims,' 148; Benite, Dao of Muhammad, 138.

53. Ford, 'Some Chinese Muslims,' 148.

54. Lipman, Familiar Strangers, 79.

55. Ford, 'Some Chinese Muslims,' 148.

56. Lipman, Familiar Strangers, 80.

57. Cited in Ford, 'Some Chinese Muslims,' 148.

58. Ibid, 148.

59. Benite, Dao of Muhammad, 138-9.

60. Ibid, 139.

61. Lipman, Familiar Strangers, 80.

62. Guangda Zhang and Jonathan Lipman, 'A Neo-Confucian Muslim Ponders the Creating God: juan 2.24a-31b of Ma Zhu's Qingzhen zhinan.' Available at: faculty.washington.edu/stevehar/zhenci.html. Accessed on: $18^{\text {th }}$ Nov. 2015.

63. Benite, Dao of Muhammad, 183.

64. Lipman, Familiar Strangers, 80

65. James D. Frankel, “'Apoliticization”: One Facet of Chinese Islam,' Journal of Muslim Minority Affairs 28, no. 3 (2008): 427-8. 
66. That Ma Zhu used his noble heritage to try and present himself as a potential leader of the Hui has not helped his credibility in this regard, see Ford, 'Some Chinese Muslims,' 149.

67. Encyclopedia of Islam, $2^{\text {nd }}$ ed., s.v. 'Liu Chih.'

68. Murata et al., Sage Learning, 4-5.

69. Benite, Dao of Muhammad, 139.

70. Encyclopedia of Islam, s.v. 'Liu Chih.'

71. Cited in Ford, 'Some Chinese Muslims,' 150.

72. Encyclopedia of Islam, s.v. 'Liu Chih.'

73. See Murata et al., Sage Learning.

74. See James D. Frankel, Rectifying God's Name: Liu Zhi's Confucian Translation of Monotheism and Islamic Law (Honolulu, HI: University of Hawai'i Press, 2011).

75. See Isaac Mason, The Arabian Prophet: A Life of Mohammed from Chinese and Arabic Sources, a Chinese Muslim Work by Liu Chia-lien (Shanghai: Commercial Press, 1921).

76. Murata et al., Sage Learning, 6-9.

77. Ibid, 8-9. Murata identifies a fourth Sufi stage, ma 'rifa (final mystical knowledge of God), which she accuses Liu Zhi of neglecting in order to maintain his threefold parallel. Sufis, however, often subsume ma 'rifa under tariqa, meaning there is not necessarily any inconsistency here.

78. Frankel, Rectifying God's Name, 101.

79. Murata et al., Sage Learning, 10-14.

80. Cited in Encyclopedia of Islam, s.v. 'Liu Chih.'

81. Murata et al., Sage Learning, 6.

82. For example, see the Egyptian Shāfi'ì jurist, Abbās Aḥmad al-Ramlī (d.1550), who issued a fatwā permitting Muslims to remain in Christian Aragon. Likewise, Rashīd Riḍā (d.1935) issued a fatwā to the same effect for Muslims living in Bosnia (then part of the Austro-Hungarian Empire), see Alan Verskin, Oppressed in the Land? Fatwās on Muslims Living under Non-Muslim Rule from the Middle Ages to the Present (Princeton, NJ: Markus Wiener, 2013), 31-4, 117-28.

83. For example, the North African scholar, Ahmad al-Wansharīsī (d.1508), roundly condemned the practice, as did the more recent Syrian scholar, Sa'īd Ramaḍān al-Būṭi (d.2013), who argued that Muslims should refrain from living in nonMuslim lands for any extended period of time, see Ibid, 21-30, 145-8.

84. Yahya Mickot, Muslims under Non-Muslim Rule: Ibn Taymiyya (Oxford: Interface Publications, 2006), 130.

85. Robert Gauvain, Salafi Ritual Purity: In the Presence of God (London: Routledge, 2013), 8.

86. Mohammad Hashim Kamali and Ahmad Badri Abdullah, 'The Fiqh al-Aqalliyāt (Jurisprudence of Minorities) in Light of the Higher Objectives (Maqāsid) of Shariah,' Islam and Civilisational Renewal 6, no.1 (2015): 115.

87. Gauvain, Salafi Ritual Purity, 4.

88. Muhammad Hashim Kamali, The Middle Path of Moderation in Islam: The Qur'anic Principle of Wasatiyyah (Oxford: Oxford University Press, 2015), 9.

89. Ibid, 10 . 